and the great problem in the temperate zones is to explain how the arthropod-borne viruses are maintained during the colder months when active insect vectors are scarce or absent. Recent investigations have shown that the young forms of several species of ticks parasitize birds, and it is thus possible that an infected tick could be transported over long distances by migrating birds. The extent and distribution of infections of man with the arthropod viruses can be determined by antibody survey work, and results of a study of residents of Athens provided evidence that the antibodies persist for at least 30 years following infection. Very valuable information has been obtained in extensive antibody surveys in the Caribbean region and a surprising finding of these immunity surveys is the wide distribution and high rate of infection with some of the recently discovered viruses.

\title{
BRITISH AGARICS AND BOLETI
}

\begin{abstract}
AECENT check-list of British agaries and boleti* A is a logical development from the revised list (1948) of Pearson and Dennis, and embodies a number of suggestions that were put forward in that work. Many unjustified names have been dropped, and a number of now records for Britain have been added. The system used follows in the main that of Singer (1949), thus being narrower than that used in the earlier list. The work is not just the compilation that the title suggests ; there are 536 pages in all, including the ancillary aecounts, and the work has involved a critical study of actual material of almost three-quarters of the species listed.

Part $1 A$ is a systematic list of genera that will be of assistance to foray secretaries and others who make lists of collections. Part $1 B$ is the check-list properan alphabetical list of genera and species with synonyms, misdeterminations, authorities and reforences. Part 2 is a list of epithots of specific, varietal and formal rank that have been used in the past, and will be of value in translating old names in terms

* New Check List of British Agaries and Boleti. By R. W. G. Dennis, P. D. Orton and F'. B. Hora. Supplement (1960) to Transactions of the British Mycological Society.
\end{abstract}

of the present list. Two papers published in association with the list (Part 3 by P. D. Orton, and Part 4 by F. B. Hora ; Trans. Brit. Mycol. Soc., 43, Pt. 2) set out a discussion of taxonomic principles which justifies the treatment given. The view is put forward that genera and species must be accurately fixed as soon as possible, but that as yet we have insufficient information on which to erect varietios and forms. Much useful advice to collectors and taxonomists is given here. Comments on the genera used in the list are given; there is a summary of changes in genera and their subdivisions ; validations of new combinations and descriptions of new species are found; and there are critical notes and keys to help understand and use the system.

The work is a massive and comprehensive undertaking, and the authors are to be congratulated on their foresight in visualizing it and on their energy in carrying it to completion. It would be strange if all mycologists were to agree with the decisions taken here : there will no doubt be those who will complain at the changes. But in the long run the sooner a stable and workable system is reached the better. This work is a major step in this direction.
D. PARK

\section{ENDEMIC AND EPIDEMIC GOITRE IN ITALY}

T HE almost legendary disease of epidemic goitre re-appeared in 1940 in the Italian Alps and Piedmont, attacking thousands of soldiers in the Province of Cunco, and in subsequent years spreading to the civil population of the other provinces of Piedmont. It died out in this part of Italy in 1945, but continued to flare up in small foci in Lombardy, Liguria, Emilia, Tuscany and Venetia up to 1948 (World Health Org., 14, No. 8 ; 1960).

The epidemic appeared in an area where endemic goitre had existed for a long time, raged for several successive years from spring to autumn, affectcd groups or individuals coming from outside the epidemic areas, and spread to regions from which endemic goitre had disappeared decades before.

The Italian epidemic of 1945-48 affected not only man but also dogs and pigs in some localities. At Monferrato it was shown that goitre appeared both in individuals drinking water from the mains and in those drawing their water from wells and tanks. Most of the goitres disappeared after some months, but some persisted and a few were still visible after some years. Administration of iodine brought no improvement and had no prophylactic effect.
Most of tho authors who have studied the Piedmont epidemic admit a relationship between epidemic and endemic goitre. This relationship, however, has been questioned in the case of Tuscany, where epidemics without endemic goitre have been known. An analysis of recent data and of the data available on succossive epidemics from the year 1700 have led $A$. Costa and M. Mortara to the conclusion that the two forms of goitre are diagnostically identical. They emphasize, in particular, the cerebral symptomatology that is clinically manifest to a greater or lesser extent in the two forms, and are inclined to the view that the central nervous system is affected, with elective, but not exclusive, localization in the autonomic centres in the dicncephalon. Costa and Mortara consider that the cerebral phenomena manifested in acute epidemic goitre might provide some clues to the cerebral changes that result in the cretinism and deaf-muteness of endemic goitro. An important fact is that endemic cretinism is still to be found in its old sites the Alps and the southern Apennines, including several surrounding hill and plain areasbut does not appear in association with endemic goitre in the south of Italy. Cretins are rare in the 